\title{
Oncogenes, Nuclear Protein
}

National Cancer Institute

\section{Source}

National Cancer Institute. Oncogenes, Nuclear Protein. NCI Thesaurus. Code C18342.

Oncogenes that encode nuclear proteins. 